University of Wollongong

Research Online

Faculty of Business - Papers (Archive)

Faculty of Business and Law

$1-1-2015$

Employer-employee congruence in environmental values: an exploration of effects on job satisfaction and creativity

Jelena Spanjol

University of Illinois at Chicago

Wing Yin Leona Tam

University of Wollongong, Itam@uow.edu.au

Vivian Tam

University of Western Sydney

Follow this and additional works at: https://ro.uow.edu.au/buspapers

Part of the Business Commons

Research Online is the open access institutional repository for the University of Wollongong. For further information contact the UOW Library: research-pubs@uow.edu.au 


\title{
Employer-employee congruence in environmental values: an exploration of effects on job satisfaction and creativity
}

\begin{abstract}
This study examines how the match (vs. mismatch) between personal and firm-level values regarding environmental responsibility affects employee job satisfaction and creativity and contributes to three literature streams [i.e., social corporate responsibility, creativity, and person-environment (P-E) fit]. Building on the P-E fit literature, we propose and test environmental orientation fit versus nonfit effects on creativity, identifying job satisfaction as a mediating mechanism and regulatory pressure as a moderator. An empirical investigation indicates that the various environmental orientation fit conditions affect job satisfaction and creativity differently. More specifically, environmental orientation fit produces greater job satisfaction and creativity when the employee and organization both demonstrate high concern for the environment (i.e., a high-high environmental orientation fit condition) than when both display congruent low concern for the environmental (i.e., a low-low environmental orientation fit condition). Furthermore, for employees working in organizations that fit their personal environmental orientation, strong regulatory pressure to comply with environmental standards diminishes the positive fit effect on job satisfaction and creativity, while regulatory pressure does not affect the job satisfaction and creativity of employees whose personal environmental orientation is incongruent with that of the organization.
\end{abstract}

\section{Keywords}

employee, employer, congruence, exploration, values, environmental, satisfaction, effects, job, creativity

\section{Disciplines}

Business

\section{Publication Details}

Spanjol, J., Tam, L. \& Tam, V. (2015). Employer-employee congruence in environmental values: an exploration of effects on job satisfaction and creativity. Journal of Business Ethics, 130 (1), 117-130. 
Running Head: Environmental Orientation Fit and Creativity

\title{
Employer-Employee Congruence in Environmental Values: An Exploration of Effects on Job Satisfaction and Creativity
}

\author{
Jelena Spanjol \\ Associate Professor of Marketing \\ University of Illinois at Chicago \\ 601 South Morgan Street \\ 2214 University Hall, MC 243 \\ Chicago, IL 60607 \\ Phone: 312-355-4953 \\ Email: spanjol@uic.edu \\ Leona Tam \\ Associate Professor of Marketing \\ School of Management, Operations and Marketing \\ University of Wollongong \\ Wollongong NSW 2522 \\ Australia \\ Phone: +61-2-4221-5578 \\ Email: ltam@uow.edu.au \\ Vivian Tam \\ Senior Lecturer of Engineering \\ University of Western Sydney \\ College of Business, Dept 3275 \\ Penrith NSW 2751 \\ Australia \\ Phone: +61-2-4736-0105 \\ Email:v.tam@uws.edu.au
}




\section{Employer-Employee Congruence in Environmental Values: An Exploration of Effects on Job Satisfaction and Creativity}

This study examines how the match (vs. mismatch) between personal and firm-level values regarding environmental responsibility affects employee job satisfaction and creativity and contributes to three literature streams (i.e., social corporate responsibility, creativity, and person-environment fit). Building on the person-environment (P-E) fit literature, we propose and test environmental orientation fit vs. nonfit effects on creativity, identifying job satisfaction as a mediating mechanism and regulatory pressure as a moderator. An empirical investigation indicates that the various environmental orientation fit conditions affect job satisfaction and creativity differently. More specifically, environmental orientation fit produces greater job satisfaction and creativity when the employee and organization both demonstrate high concern for the environment (i.e., a high-high environmental orientation fit condition) than when both display congruent low concern for the environmental (i.e., a low-low environmental orientation fit condition). Furthermore, for employees working in organizations that fit their personal environmental orientation, strong regulatory pressure to comply with environmental standards diminishes the positive fit effect on job satisfaction and creativity, while regulatory pressure does not affect the job satisfaction and creativity of employees whose personal environmental orientation is incongruent with that of the organization.

Keywords: Environmental Orientation; Creativity; Corporate Social Responsibility; PersonOrganization Fit; Job Satisfaction 
"In a finite world, the only way that humanity can sustain economic and social development is through innovation" Jacqueline McGlade, Executive Director, European Environment Agency

\section{Introduction}

Evidence is mounting that firms can benefit significantly from embracing a "green imperative.” Proactively adopting and implementing environmentally-friendly strategies beyond mere compliance translates into greater market share (Menguc and Ozanne, 2005), improves consumer beliefs and attitudes (Becker-Olsen, Cudmore, and Hill, 2006), and enhances future financial performance (Waddock and Graves, 1997). Positive consequences from enacting environmentally-friendly strategies accrue to firms both large and small (Clemens, 2006). When firms discontinue to actively enact socially responsible strategies, they can be punished in financial markets. Becchetti et al. (2012), for example, demonstrate in a sample of 278 firms across 14 years that those who exit from the Domini 400 Social Index (i.e., a stock market index based on social responsibility) experience an immediate significant negative effect on abnormal returns. Given this increasing empirical evidence, firms are well advised to integrate environmental responsibility into their culture, strategy, and actions.

While much of the business literature has focused on financial and market outcomes from corporate environmental responsibility, researchers lack a thorough understanding of the impact on employee attitudes and behaviors (Menguc and Ozanne, 2005). For example, extant literature does not provide clear insight into how employee creativity might be enhanced (or diminished) by a firm’s stance towards the environment. Employee creativity is a particularly salient organizational aspect (Tang, 2010), since environmentally conscious companies pursue their mission through engaging in innovation (Shrivastava, 1995), seeking to enhance new product performance (Chen and Chang, 2013). In turn, it has been demonstrated that innovation increases 
a firm's market value (Sorescu and Spanjol, 2008). General Electric’s Ecomagination initiative, for example, has produced over 80 new products and services (such as energy-efficient MRIs and light bulbs) since its inception in 2004, leading to \$17 billion in annual revenue and over \$100 million in cost savings (Kauffeld, Malhotra, and Higgins, 2009).

A study of 599 firms across 28 countries demonstrates that innovation (along with human capital and culture) fully mediates the positive relationship between corporate social responsibility and a firm’s financial performance (Surroca, Tribo, and Waddock, 2010). Motivated by a large literature with heterogeneous results on corporate social responsibility’s (CSR) effect on organizational financial performance, Surroca et al. (2010) proposed that these inconsistent results could be explained by two missing mediators: innovation and human capital. They empirically assessed innovation as the ratio of $R \& D$ expenses relative to the number of employees in a firm and human capital as an organization's overall level of employee job satisfaction (among other dimensions). Thus, at the organizational level, innovation was measured as an input variable (via investment). Surroca et al. (2010) confirmed empirically that innovation and human capital mediate the effects of corporate social responsibility (including environmental) initiatives on organizational performance, which in turn creates a "virtuous cycle” to enhance CSR further.

Given these results, the question arises as to what the mechanisms are (at the more granular employee level) that render innovation and human capital necessary components to successful and beneficial CSR initiatives. Our study proposes that one potential mechanism at the employee level is enhanced creativity under conditions of employee-employer value congruence. In turn, creativity has been argued to be the "first step that is necessary for subsequent innovation” (Shalley, Zhou, and Oldham, 2004). Thus, our study addresses a gap in 
the literature on potential employee-employer congruence effects on employee creativity that is of concern to both innovation and corporate social responsibility scholars and practitioners.

Our study examines how the match (vs. mismatch) between personal and firm-level environmental orientations affects employee creativity. Building on the person-environment (PE) fit literature, we propose and test environmental orientation fit vs. nonfit effects on creativity, identifying job satisfaction as a mediator. The study also identifies boundary conditions for fit effects on job satisfaction and creativity based on the intensity of regulations the firm faces. As a result, this study contributes to three literatures: corporate social responsibility, creativity, and person-environment fit.

The remainder of this paper is organized as follows. Section 2 briefly discusses relevant theoretical and empirical literature, which underlies the hypotheses. Section 3 describes the empirical study, including data, method, and results, while section 4 draws implications for theory and practice and discusses limitations and future research.

\section{Environmental Orientation and Creativity at the Firm and Employee Level}

Firms with a strong environmental orientation (EO) seek to develop ecologically sustainable relationships with their environment (Shrivastava, 1996). More formally, environmental orientation is the "recognition of the legitimacy and importance of the biophysical environment in the formulation of organization strategy, and the integration of environmental issues into the strategic planning process” (Banerjee, 2002, p. 181). This rather encompassing conceptualization of environmental orientation implies that it plays out at multiple levels (Banerjee, 2001). At the organizational level, C-suite executives determine the extent to which firms place strategic emphasis on corporate social responsibility in general (Aragon-Correa, 
Matias-Reche, and Senise-Barrio, 2004; Sharma, 2000) as well as specific environmentallyoriented initiatives such as green purchasing (Yen and Yen, 2012).

However, the enactment of an environmental orientation is not a top-down process. Individual employees are instrumental in creating and realizing corporate social responsibility activities, which encompass those focused on the environment (Bolton, Kim, and O'Gorman, 2011). In a longitudinal ethnographic case study, Bansal (2003) finds that the presence of individual employees' environmental concerns makes organizations more likely to respond to ecological sustainability issues. Furthermore, recent studies have called for additional research into how internal stakeholders (i.e., employees; Hansen et al., 2011) translate environmental initiatives into enhanced firm performance. A critical mediating mechanism through which a strong environmental orientation enhances a firm's financial performance is innovation (Surroca et al., 2010). In order for firms to innovate, however, individual employees have to be creative (Amabile et al., 1996), as individual creativity is the building block for organizational innovation (Amabile, 1988).

Creativity is defined as the "production of new and useful ideas concerning products, services, processes, and procedures” (Zhou and Shalley, 2003, p. 167; Woodman, Sawyer, and Griffin, 1993). In the context of an organizational work environment, creativity captures not only the employee's ability to generate inventive input into their daily work, but also refers to employees' beliefs that creativity is called for and enabled in their work environment (Amabile et al., 1996). Thus, our study examines employees’ perceptions regarding their own creativity and how conducive their workplace is to creativity.

The characteristics of individual employees and those of the organizational context interact to influence creativity (Woodman et al., 1993), and both individual employees' concerns 
with and organizational values regarding environmentally-related issues are critical in determining the scope and speed of environmentally-responsible initiatives (Bansal, 2003). However, extant research gives no clear guidance on how employee values interact with organizational ones to affect creativity (Shalley, Zhou, and Oldham, 2004). Thus, our study explores the interaction between employee and organizational values regarding the environment via the person-environment fit framework, focusing specifically on the effects from congruence between employee and firm environmental orientations (i.e., EO fit) on creativity.

\subsection{Environmental Orientation Fit and Creativity}

Person-environment (P-E) fit is "the compatibility that occurs when individual and work environment characteristics are well matched” (Kristof-Brown and Guay, 2011, p. 3). P-E fit is based on the interactional psychology tradition and premise that individual behavior is a function of both a person's characteristics and those of the environment within which the individual acts. A more focused stream of P-E fit research examines person-organization (P-O) fit, which refers to the congruence or compatibility between values and norms of individual employees and those of the employing firm (Chatman, 1989; Kristof, 1996). While the P-O fit literature covers many diverse outcome variables—such as personnel selection and organizational design, among others - it has not examined the effects of (in)congruence between employees' and employers' attitudes towards the environment and consequences for job satisfaction and creativity.

In general, the P-O fit literature demonstrates positive outcomes on employee wellbeing in their work environment when congruence is enhanced (O'Reilly, Chatman, and Caldwell, 1991). The most frequently examined outcomes from P-O fit are job attitudes, such as job satisfaction, commitment to the organization, and turnover intent. The supplementary fit perspective argues that the similarity between employee and organizational values produces 
compatibility, which results in employees reporting greater trust in the organization and a greater ease of communication, in turn enhancing employee job satisfaction (Cable and Edwards, 2004; Edwards and Cable, 2009). The complementary fit perspective suggests that when employee and firm values are congruent, employees find themselves working in an environment that is able to fulfill their needs. Thus, the enhanced job satisfaction from P-O fit can be a result from the organization meeting certain needs of the employee (Cable and Edwards, 2004; Edwards and Cable, 2009). Both perspectives are "based on the premise that people have positive attitudes toward—and want to remain part of —-work environments in which they feel positive reinforcement” (Kristof-Brown and Guay, 2011, p. 13).

Extant P-O fit literature does not offer clear insight into how value congruence might affect creativity in employees. P-O fit only weakly associates with employee task-related performance (Kristof-Brown, Zimmerman, and Johnson, 2005), due to the fact that task-related performance depends critically on an employee’s job proficiency, rather than on value congruence (Kristof-Brown and Guay, 2011). In contrast, P-O fit significantly enhances contextual performance, which includes positive citizenship behaviors, supporting the organization's mission, and putting in extra effort (Arthur et al., 2006; Kristof-Brown et al., 2005). Kristof-Brown and Guay (2011) suggest that P-O fit leads to "behaviors motivated by assisting the organization, not just performing a job” (p. 34). One such contextual performance aspect is employee creativity.

In the educational setting, Choi (2004) finds that when the desired and perceived levels of creative climate in the classroom are congruent, students report being most creative. A study of R\&D employees concludes that when the employees and their supervisors have congruent and high levels of intrinsic motivation, employees are at their most creative (Tierney, Farmer, and 
Graen, 1999). Greater motivation results from greater job satisfaction, which increases when employees experience greater ethical fit with their employing organizations (Ambrose, Arnaud, and Schminke, 2008). Employees who feel that their work environment is supportive also engage more readily in creative ways to solve problems they might encounter at work (Oldham and Cummings, 1996). While the literature has not linked job satisfaction directly to creativity, empirical evidence suggests that supportive supervision and climate enhance employee creativity (Shalley, Zhou, and Oldham, 2004) and that supportive climates correlate with job satisfaction (Podsakoff, MacKenzie, and Bommer, 1996). Furthermore, an encouraging organizational context is a critical factor in enhancing creativity in employees (Amabile et al., 1996; West and Farr, 1990).

In the context of environmental values and norms, greater environmental orientation fit is likely to enhance job satisfaction and in turn employee creativity. Congruence on environmental orientation can occur under two conditions: when both employee and organization place high emphasis on environmental responsibility, or when both employee and organization place low emphasis on environmental responsibility. According to P-O fit theory, employees will experience greater satisfaction and creativity due to similarity effects (i.e., supplementary fit perspective), regardless of the category of fit. In addition, for employees who are highly environmentally conscious, working for a firm that also places high emphasis on environmental responsibility will allow them to fulfill their needs better (i.e., complementary fit perspective). In other words, similarity benefits accrue to both high-high and low-low conditions of fit, but needs-fulfillment benefits only accrue to the high-high fit condition. That is, since low environmental values mark a low-low fit situation (i.e., where both the employee and the 
organization display low levels of environmental orientation), no values-based needs are being fulfilled.

Formally stated, we hypothesize that a fit between an employee's and the firm's environmental orientation enhances job satisfaction, which in turn enhances creativity. That is, environmental orientation fit indirectly enhances creativity through job satisfaction.

$\mathrm{H}_{1}$ : Greater environmental orientation fit leads to greater job satisfaction.

$\mathrm{H}_{2}$ : Greater job satisfaction leads to greater creativity.

$\mathrm{H}_{3}$ : Job satisfaction mediates the positive relationship between environmental orientation fit and creativity.

\subsection{Regulatory Pressure as a Moderator of the Environmental Orientation Fit-Job Satisfaction-Creativity Relationship}

External contextual characteristics in which the firm operates can limit the hypothesized positive effects of environmental orientation fit on job satisfaction and creativity. In particular, the intensity of regulations that put pressure on firms to adopt environmentally-friendly practices is one of the foremost reasons why companies implement ecologically-responsible initiatives and policies (Dangelico and Pujari, 2010). When compliance with regulations is a major factor for companies to go green, in order to avoid "risks of activity breakdown, money losses or damage to the company image” (Dangelico and Pujari, 2010, p. 474), ecologically-responsible initiatives can create frictions within the firm. Greater intensity of regulations (either imposed by governmental agencies or industry codes) can lead to lower job satisfaction, as it creates a work environment that is more stressful due to the severity of potential punishments. Similarly, greater regulatory pressure can reduce creativity. Thus, this research hypothesizes that the positive effect 
of environmental orientation fit on job satisfaction and creativity diminishes as regulatory pressure becomes more severe.

$\mathrm{H}_{4}$ : The positive relationship between environmental orientation fit and creativity (mediated by job satisfaction) is negatively moderated by regulatory pressure. Figure 1 summarizes the hypotheses and graphically represents the conceptual model.

-- Figure 1 here --

\section{Method}

\subsection{Participants and Procedure}

To test the hypotheses regarding environmental orientation fit, we surveyed full-time engineering employees. This study focuses on engineering personnel for two reasons. First, technical employees are directly responsible for developing and implementing environmentally friendly solutions, and thus understanding what conditions support their creativity is important. Second, surveying only engineering personnel eliminates the potential confounding effects from surveying multiple disciplines (such as sales, finance, and marketing).

To measure the constructs in our conceptual model, all current members of a major engineers’ association in Australia received an email link to an anonymous online survey. Participation in the survey entered respondents into a lucky draw to win one of four AU\$50 gift cards. Email invitations to the 836 email addresses in the database generated a total of 94 online responses. The final sample excludes four incomplete responses, constituting an effective response rate of $11 \%$. The final sample is similar to the population (i.e., full membership of the engineering association) in both gender and age (17\% women; $27 \%$ in the $50-59$ age range), and thus non-response bias is not deemed to be a significant concern. We note that our response rate is similar to that of other recent business ethics studies that employ a web-based survey method 
(e.g., Chowdhury and Fernando, 2013; Jin, Drozdenko, and DeLoughy, 2013). Our model also accounts for a number of organizational and employee demographic characteristics in terms of control variables. Table 1 summarizes demographic characteristics of the respondents.

-- Table 1 here --

\subsection{Measures}

We pre-tested all measures with 61 full-time employees who were also part-time students taking classes at a large university in the United States. Our objective in conducting the pretest was two-fold: establish the reliability of the measures and ensure that the length of the online questionnaire was acceptable to ensure quality responses. The pretest confirmed that the measures were reliable, exceeding the 0.70 benchmark set forth by Nunnally (1978): employee environmental orientation $=0.88$; company environmental orientation $=0.96$; job satisfaction $=$ 0.85 ; creativity $=0.95$; and regulatory pressure $=0.75$. The survey was also not unduly taxing to respondents who took an average of 21 minutes and 35 seconds to complete the instrument. As a result, no adjustments to the survey instrument were deemed necessary based on the pretest.

In the main study, participants answered questions about their personal concern for the environment and attitudes towards environmentally-friendly products, as well as questions about the environmental orientation of the organization they worked for at the time of this study. Employees also reported on job outcome variables (i.e., job satisfaction and creativity), demographic variables, and control variables. Except for the demographic information, all ratings are on 7-point Likert scales ( 1 = strongly disagree, 7 = strongly agree). All multiple-item measures show adequate reliability (all reliability coefficients $>0.71$ ). Furthermore, all constructs display adequate discriminant validity, as no correlation is greater than the 
corresponding square root of average variance extracted ( $\sqrt{ } A V E$; Fornell and Larcker, 1981).

Table 1 summarizes all inter-construct correlations and $\sqrt{ } A V E$ values.

Employee Environmental Orientation. The employee’s individual environmental orientation measure uses a modified 8-item dispositional innovativeness scale by Steenkamp and Gielens (2003) ( $\alpha=0.91)$. This scale taps into actual behaviors of employees in their personal realm, which reduces the potential overlap or confounding with their views on corporate environmental responsibilities. That is, if the survey had inquired about employees’ individual values regarding environmental conservation and their views on their firm's values, a confound effect would have been highly likely. While the original Steenkamp and Gielens (2003) scale assesses an individual's overall predisposition to purchase new products or brands and change consumption patterns, the modification of the scale translates this behavioral disposition into the environmentally-friendly context. For example, one of the items in the original scale is "I am usually among the first to try new brands.” In the modified version, this item reads "I am usually among the first to try 'green’ and environmentally-friendly brands.”

Organizational Environmental Orientation. The employee's perception of his or her company’s environmental orientation measure uses the 7-item corporate social responsibility (CSR) scale developed by Menguc and Ozanne (2005) $(\alpha=0.93)$. This scale is particularly relevant to the current study of fit between an individual's and his/her employer's attitudes towards environmental conservation, as it captures a "set of environmental management principles” and behaviors (Menguc and Ozanne, 2005, p. 434). The scale focuses on specific environmentally-oriented behaviors and activities within the firm (such as reducing physical waste through recycling), rather than a more general value assessment of a firm's environmental consciousness. For example, one of the items in Banerjee’s (2002) measure of environmental 
orientation asks respondents to rate the statement "Our firm has a responsibility to preserve the environment.” Given the current study’s focus on assessing the congruence between environmental orientations at the employee and firm level, such items might confound the findings as they are likely to also tap into personal convictions. Finally, the current measures of employee- and firm-level environmental orientations satisfy the need for measuring commensurate dimensions of the P-O fit (Edwards, Caplan, and Harrison, 1998).

Environmental Orientation (EO) Fit for Mediation and Moderation Effects Testing. The fit index between an employee’s personal environmental orientation and his or her firm’s environmental orientation is constructed as the cross-product interaction between these two variables. Following Aiken and West (1991), the fit index computation uses centered scores of both employee and organizational environmental orientations.

Job Satisfaction. The employee’s general job satisfaction measure includes the 5-item scale ( $\alpha=0.85$ ) developed by Dubinsky, Howell, Ingram, and Bellenger (1986) and recently validated by Koonmee, Singhapakdi, Virakul, and Lee (2010).

Creativity. The creativity measure uses the 6-item scale $(\alpha=0.95)$ developed by Amabile, Burnside, and Gryskiewicz (1995). The scale assesses employees’ beliefs and perceptions about how creative their area of work is, how much creativity is called for in their daily work, and the level of creativity they display. As Amabile et al. (1996) note, this more comprehensive measurement of creativity in the workplace (as opposed to an outcome-specific creativity assessment) corresponds to the "total-work-environment level of analysis” approach (p. 1157), which aims to tap into the holistic perceptions of the individual employee regarding their own creativity at work. Tapping such perceptions is important since "it is the psychological 
meaning of environmental events that largely influences creative behavior” (Amabile et al., 1996, p. 1158). ${ }^{1}$

Regulatory Pressure. To capture the intensity of regulations to comply with environmentally-friendly standards, the 6-item scale developed by Stone and Wakefield (2000) $(\alpha=0.73)$ is adapted. The scale assesses the relative level of regulation applied to the industry in which the firm operates, including the severity of possible penalties imposed on firms that do not follow the regulations.

Control Variables. The analyses include several control variables. First, this study accounts for the influence of organizational encouragement in employees' job satisfaction and creativity reports, as previous research repeatedly found that a supportive and encouraging work climate is a highly significant predictor of workplace wellbeing and creativity (Amabile et al., 1996; Podsakoff et al., 1996; Shalley et al., 2004). The organizational encouragement measure uses the 15 -item scale ( $\alpha=0.97$ ) developed by Amabile, Burnside, and Gryskiewicz (1995).

The second set of control variables encompasses participants' demographic information including gender, age, educational level, how long the employee has worked at the current organization and in the current position, and number of employees in the organization. None of the demographic characteristics show significant and systematic effects on the dependent variables in the analyses.

Finally, the analysis also includes a control variable to assess any potential social desirability effects by using the Strahan and Gerbasi (1972) scale $(\alpha=0.71)$. Since concern for

\footnotetext{
${ }^{1}$ To ensure that the creativity scale worked as intended and captured employees' perceptions of their own creativity, we conducted all analyses involving the creativity variable also with only one item representing a direct measure of the employee's perceived creativity at work (i.e., "I believe that I am currently very creative at my work"). All analyses yielded essentially the same results with both the full creativity scale and the one-item creativity measure, confirming that the creativity scale captured the construct adequately.
} 
the physical environment is generally a desirable attitude, the current study aims to rule out any bias in participants' responses due to their tendency to provide socially acceptable answers. Results reveal no systematic effects of social desirability in any of the analyses.

\subsection{Results}

Following the literature examining fit hypotheses (e.g., Jordan et al., 2013; Schminke, Ambrose, and Neubaum, 2005), we employ polynomial regressions and response surface methodology (Edwards and Parry, 1993) to test our fit hypothesis, which involves the effect of congruence between the employee's and organization's environmental orientations (i.e., EO fit effects). The polynomial regression analyses involve estimating a quadratic regression model with job satisfaction or creativity as the dependent variable (Z) and both individual (X) and organization (Y) environmental orientations as the independent variables. The full polynomial equation is given as:

$$
Z=b_{0}+b_{1} X+b_{2} Y+b_{3} X^{2}+b_{4} X Y+b_{5} Y^{2}+e
$$

Results of these regression analyses are presented in Table 2 and the corresponding surfaces are shown in Figures 2 and 3. In these figures, the employee's and organization’s environmental orientation (EO) scores are located on the X, Y plane, or the "floor" of the graph. Job satisfaction and creativity are located on the Z-axes, that is, the vertical axis extending up from the floor of the graph. The line of fit, that is where $X=Y$, is the line that extends from the front to the back of the graph.

\section{-- Table 2 here --}

Questions regarding the impact of congruence or fit on job satisfaction and creativity explore the shape of the surface along various lines of interest. One of these is the line along which employee and organization environment orientations are equal and are, thus, congruent. This is the $\mathrm{X}=\mathrm{Y}$ line, which extends from the nearest to the farthest corners of the $\mathrm{X}$, $\mathrm{Y}$ plane. To focus on the $\mathrm{X}=\mathrm{Y}$ line, the axes in Figures 2 and 3 are oriented in a way to better illustrate the hypothesis testing results. 
-- Figures 2 and 3 here --

Tests for the hypotheses provide a finer grained analysis of the effect of environmental orientation fit. We predicted that job satisfaction and creativity will increase as employee and organizational environmental orientations become congruent. Thus, our interest lies in what happens to the surface along the $\mathrm{X}=\mathrm{Y}$ line. Following Edwards (2002), the fit hypotheses may be tested by setting $\mathrm{X}$ equal to $\mathrm{Y}$ in the polynomial equation above and solving for $\mathrm{X}$ and $\mathrm{X}^{2}$, which represent the slope and curvature of the surface, respectively. Doing so reveals that the curvature of the surface along the $X=Y$ line is represented by the quantity $b_{3}+b_{4}+b_{5}$, and the slope of the surface at the point $\mathrm{X}=0$ (and, thus, $\mathrm{Y}=0$ as well) is represented by $\mathrm{b}_{1}+\mathrm{b}_{2}$. These values, which may be calculated from the polynomial regression coefficients reported in Table 2, reveal important features of the shape of the surfaces. For example, a positive value for the quantity $b_{3}+b_{4}+b_{5}$ indicates a concave (bowl-shaped) surface, and a negative value indicates a convex (dome-shaped) surface along the $\mathrm{X}=\mathrm{Y}$ surface. Likewise, a positive value for the quantity $b_{1}+b_{2}$ at the point $X=0$ indicates that the surface is increasing as it crosses the $X=Y$ line, and a negative value indicates it is decreasing. A value of zero indicates the surface has achieved its maximum (or minimum) along the $\mathrm{X}=\mathrm{Y}$ line.

Following Edwards and Rothbard (1999), support for our hypotheses requires that two conditions hold. First, the shape of the surface along the $\mathrm{X}=\mathrm{Y}$ line must exhibit the anticipated curvature. In this case, we predicted that job satisfaction and creativity will improve as congruence increases, which implies a convex surface (bowl-shaped) for job satisfaction and creativity along the line of $X=Y$. As indicated by the significant positive values for $b_{3}+b_{4}+b_{5}$ in Table 2, this condition held for both job satisfaction and creativity. Second, the slope of the surface along the $\mathrm{X}=\mathrm{Y}$ line must be in the anticipated direction. In our case, that implies the slope of the surfaces as they cross the $\mathrm{X}=\mathrm{Y}$ line would be positive for job satisfaction and creativity. As indicated by the significant positive values for $b_{1}+b_{2}$ in Table 2 , this condition was met for both job satisfaction and creativity. Together, these results provide strong support for our expectation that job satisfaction and creativity are most positive under conditions of 
environmental orientation fit.

Recall that we did not hypothesize about the effect of incongruence (e.g., incongruence reflected by a lower level of employee than organizational environmental orientation, or incongruence reflected by a higher level of employee than organizational environmental orientation) on job satisfaction and creativity. Rather, we proposed exploratory analysis of this issue. This involves examining the shape of the surface along the $\mathrm{X}=-\mathrm{Y}$ line and the information shown in Table 2. Applying the same method as above (Edwards and Rothbard, 1999), the shape of the surface along this line can be tested by setting $\mathrm{X}$ equal to $-\mathrm{Y}$ in the polynomial equation above and again solving for $\mathrm{X}$ and $\mathrm{X}^{2}$. Doing so reveals that the curvature of the surface along the $\mathrm{X}=-\mathrm{Y}$ line is represented by the quantity $\mathrm{b}_{3}-\mathrm{b}_{4}+\mathrm{b}_{5}$ and the slope of the surface at the point $\mathrm{X}=0$ (thus, $\mathrm{Y}=0$ as well) is represented by $\mathrm{b}_{1}-\mathrm{b}_{2}$. These values are reported in Table 2 labeled "Shape along the $\mathrm{X}=-\mathrm{Y}$ line” and reveal that the surfaces for job satisfaction and creativity are concave (dome-shaped) along the $\mathrm{X}=-\mathrm{Y}$ line, as indicated by the significant negative values for $b_{3}-b_{4}+b_{5}$

Our tests of the congruence hypotheses support that job satisfaction and creativity are greater when organizational and employee environmental orientations are congruent (i.e., along the $\mathrm{X}=\mathrm{Y}$ line) than incongruent. Furthermore, the results also suggest that job satisfaction and creativity are maximized when congruence results from high levels of environmental orientation on the part of both employee and organization. The positive effect of congruence is least pronounced when it reflects low levels of environmental orientation in both employee and organization. In other words, similarity benefits accrue to both high-high and low-low conditions of EO fit, but needs-fulfillment benefits only accrue to the high-high fit condition. Therefore, $\mathrm{H}_{1}$ and $\mathrm{H}_{2}$ are supported.

In view of the non-significant effects of the quadratic terms of employee and organization environmental orientations (Table 2) and the difficulty of applying response surface methodology to an analysis involving four dimensions (two independent variables, one moderator, and one dependent variable), the quadratic terms of employee and organization 
environmental orientations are dropped from the mediation and moderation analyses from this point on.

Job Satisfaction as a Mediator in the Environmental Orientation Fit-Creativity Relationship. $\mathrm{H}_{3}$ states that job satisfaction mediates environmental orientation fit's positive effect on creativity. In order to test the mediation hypothesis, we employ the rigorous approach suggested by Zhao, Lynch, and Chen (2010) instead of Baron and Kenny’s (1986) more commonly used methodology. Zhao et al. (2010) point out a number of issues with the Baron and Kenny (1986) procedure and suggest a revised testing approach that provides a more nuanced analysis of mediation effects. These authors recommend replacing the Baron-Kenny "three tests + Sobel” approach with a single bootstrap test of the indirect (mediated) effect (which is the multiplicative product of the path from the independent variable to the mediator and the one from the mediator to the dependent variable; Preacher and Hayes, 2008; see Zhao et al., 2010, for a detailed discussion).

The findings reveal the mean indirect effect for job satisfaction from the bootstrap analysis as positive and significant (0.2108), with a 95\% confidence interval excluding zero (0.0645 to 0.3519). In the indirect path, a unit increase in environmental orientation fit increases job satisfaction by 0.2747 units on a 1 to 7 scale; holding environmental orientation fit constant, a unit increase in job satisfaction increases creativity by 0.7672 units on a 1 to 7 scale. Furthermore, the direct effect (0.2437) of environmental orientation fit on creativity is also significant ( $p=0.01)$; holding constant job satisfaction, a unit increase in environmental orientation fit increases creativity by 0.2437 on the 1 to 7 scale. Since the indirect effect is significant and the product term of direct and indirect effects for job satisfaction is positive $(0.2108 * 0.2437=0.0514)$, we conclude that job satisfaction is a complementary mediator for environmental orientation fit. Using Baron and Kenny’s (1986) terminology, these findings may be interpreted as indicating that job satisfaction is a partial mediator. Table 3 summarizes the mediation analysis results. 
Regulatory Pressure as a Moderator. $\mathrm{H}_{4}$ posits that regulatory pressure negatively moderates the relationship between environmental orientation fit and creativity (in addition to the mediating effect of job satisfaction). We construct a regression model to predict job satisfaction from employee environmental orientation, organizational environmental orientation, environmental orientation fit, regulatory pressure, the interaction term between regulatory pressure and environmental orientation fit (capturing the hypothesized moderating effect), and the control variables of organizational encouragement, participants' gender, age, education level, tenure at current organization, number of years in current position, and number of employees at organization. Table 4a displays the regression results, which indicate that the interaction between regulatory pressure and environmental orientation fit significantly and negatively affects job satisfaction $\left(\beta=-0.23, p<0.01\right.$ ), in support of $\mathrm{H}_{4}$. Furthermore, Table $4 \mathrm{~b}$ illustrates that the reduced positive effect from environmental orientation fit on job satisfaction still carries over into greater creativity under fit compared to nonfit conditions, as job satisfaction remains a significant predictor of creativity $(\beta=0.24, p<0.05)$ even after adding the EO fit*regulatory pressure interaction term.

-- Tables 3, 4a, and 4b here --

Further decomposition of the simple regressions probes the relation between environmental orientation fit and job satisfaction separately for higher and lower regulatory pressure. Figure 4 shows the results of the simple slope decomposition. The simple slopes of the relation between environmental orientation fit and job satisfaction become negative and significant for high regulatory pressure (nonstandardized beta $=-0.47, p<0.01$ ) but are not significant for those under low regulatory pressure (nonstandardized beta $=0.15, p=0.09$ ). In other words, the positive environmental orientation fit effect on job satisfaction only maintains at 
low levels of regulatory pressure. For employees working in organizations that fit their personal environmental orientation, high regulatory pressure disrupts the positive fit effect on job satisfaction. Examination of the means provides further evidence of the non-significant difference of job satisfaction levels in employees working under high fit and high regulatory pressure $(M=4.63)$ and those working under low fit and high regulatory pressure $(M=4.91)$. Therefore, the findings support $\mathrm{H}_{4}$.

-- Figures 4 and 5 here --

To fully understand the interaction effects between regulatory pressure and environmental orientation fit, we also decompose the interaction term to identify whether any differences between the four types of environmental orientation fit conditions exist. Figure 5 demonstrates that both high-high and low-low environmental orientation fit conditions significantly drop in job satisfaction under high regulatory pressure when compared to low regulatory pressure. While the drop in job satisfaction is proportional in both fit conditions, employees in the high-high fit condition have greater job satisfaction levels under both low $(M=$ 5.95) and high $(M=4.94)$ regulatory pressure when compared to employees in the low-low fit condition ( $M=5.33$ and $M=4.32$, respectively). This result suggests that complementary and supplementary environmental orientation fit effects on job satisfaction function additively only in high-high fit employees.

Both nonfit conditions show non-significant simple slopes $(\beta=0.14, p=0.13)$. This result indicates that employees with environmental orientations that are mismatched with that of their organization are equally satisfied in their jobs regardless of the intensity of regulatory pressure. It is of interest to note that under high regulatory pressure, employees in the nonfit 
conditions are more satisfied $(M=4.89$ and 4.92) than those employees whose low environmental orientation matches that of the organization (i.e., low-low fit; $M=4.32$ ).

\section{Discussion}

\subsection{Theoretical Implications}

This study contributes insights to three literature streams - person-environment fit, creativity, and social corporate responsibility research. First, this study contributes to the personenvironment (P-E) fit literature by identifying and empirically assessing a value-based fit construct (i.e., environmental orientation fit). The model in this study explores an underresearched outcome domain in P-E fit research, namely creativity (Kristof-Brown and Guay, 2011). Our empirical study lends support to the theory that environmental orientation fit operates simultaneously yet independently via two different value-enhancing mechanisms (Cable and Edwards, 2004) - psychological need fulfillment (complementary fit effect) and value congruence (supplementary fit effect). More specifically, environmental orientation fit produces greater job satisfaction and creativity when the employee and organization both care highly about the environment (i.e., a high-high fit condition) than when both display congruent low environmental orientations (i.e., a low-low fit condition). This finding suggests that only the value congruence mechanism is at work in the low-low fit condition, while employees in the high-high fit condition are able to fulfill their psychological needs tied to eco-friendly attitudes and behaviors and get an additional boost in job satisfaction and creativity via the complementary fit mechanism.

Second, the findings in this study contribute to the literature on creativity by directly addressing the call to study contextual factors and how they interact with employee characteristics to affect creativity (Shalley and Zhou, 2008; Woodman et al., 1993). The model 
proposed and tested in this study addresses Zhou and Shalley's (2011) call to examine mediating factors in creativity effects. The present findings indicate that creativity is indirectly enhanced by environmental orientation fit through increased job satisfaction.

Third, this study contributes to the broader corporate social responsibility (CSR) literature by exploring how environmentally-minded values in firms affect an important performance aspect that has been understudied in this literature, namely creativity. More specifically, we build on recent insights generated by Surroca et al. (2010), who use secondary data at a firm level to identify innovation (measured by the ratio of R\&D spending per employee) as a mediator between a firm’s multidimensional corporate responsibility rating (including environmental initiatives) and the firm’s financial performance (i.e., Tobin’s q). In addition to innovation, Surroca et al. (2010) also identify human capital (measured multi-dimensionally in terms of “job satisfaction, training programs, profit-sharing programs and employee participation, and the introduction of indicators to seek information about employees”, p. 475) as a mediator. While Surroca et al. (2010) identify these firm-level effects of innovation input (i.e., R\&D investment per employee) and employee standing as critical, their study is silent on the employee-level mechanisms through which innovation and human capital mediators work. Our study provides evidence regarding one such employee-level, granular mechanism by demonstrating how creativity (as a necessary precursor to innovation output) is enhanced under different conditions of environmental orientation fit.

\subsection{Managerial Implications}

The empirical results suggest that managers should carefully select personnel to work on eco-friendly innovation initiatives since employees with a high personal environmental orientation will likely be happier to engage with such initiatives and demonstrate greater 
creativity. In particular, managers should be aware of the significant decrease in creativity that employees experience when their low concern for the environment is mismatched with the organization’s high environmental orientation. To counteract lower job satisfaction and creativity from such mismatched environmental orientations, organizations might look for other ways to boost employee well-being.

The finding that regulatory pressure moderates the environmental fit-job satisfaction relationship also carries important implications. Employees experiencing environmental orientation mismatch appear to be resistant to the potential stress from greater regulatory pressure, as they report similar job satisfaction levels under both high and low regulatory pressure. When regulations are highly stringent, employees whose environmental orientation does not fit that of their employing organization report greater job satisfaction (and hence creativity) than employees whose low environmental orientation fits with that of the firm. In essence, a low-low environmental orientation fit magnifies the stress from greater regulatory pressure, since both the employee and his or her employer are not inclined to enact an environmentally-friendly stance. In contrast, the disconnect between employees and their employers under environmental orientation nonfit insulates the employee from the additional stress created by greater regulatory pressure. These findings imply that if firms have limited latitude in terms of personnel assignment (e.g., the organization cannot afford to exclusively hire employees with matching environmental orientations for financial or applicant pool limitations), managers should assign employees matching the company’s environmental orientation to departments and tasks that are under relatively low regulatory pressure and require creativity. 


\subsection{Limitations and Future Research}

Several limitations of this research exist and point to future research opportunities. First, while the model tested in this paper controls for organizational encouragement in order to produce a more conservative and rigorous test of environmental orientation fit effects on job satisfaction and creativity, it is possible that organizational encouragement might be perceived differently by employees whose environmental orientation fits well with that of the organization. The data in this study do not allow for such an exploration and future research should examine potential differences.

The study is also limited by its cross-sectional and single informant design. While the sample eliminates a function-based confound by surveying engineers only, it also restricts the generalizability of the findings to other functions. Since creativity is contextual, environmental orientation fit might affect marketing creativity directly (in addition through job satisfaction) and more strongly, if marketing personnel is actively engaged in uncovering environmentallyresponsible needs in the firm's customer base. Thus, a high-high fit condition might enhance job satisfaction and creativity even more, and a nonfit condition might be more detrimental than among technical employees. It is possible that triangulating data from different sources (employees, supervisor, etc.) might strengthen the conclusions drawn from the findings. For example, asking third parties to provide ratings of the firm's environmental orientation might remove single informant bias. However, in any person-organization value-based fit research, the most relevant perception of organizational values is arguably the employee's (Kristof-Brown and Billsberry, 2013) and we follow the literature stream of "subjective fit" in which fit is indirectly observed and calculated by asking the employee to report on both internal and external elements. 
From a conceptual standpoint, asking employees to rate both their own and their company's environmental orientation (EO) is in line with the underlying logic that an employee's perceived EO fit is what determines whether employees self-select into working for certain organizations and not others. For example, Brekke and Nyborg (2008) develop a model that suggests a firm's environmental orientation (along with other corporate social responsibility investments) can act as a labor market screening mechanism, allowing "green” (i.e., socially responsible) firms to attract more productive workers. Furthermore, recent research suggests that employee perceptions of their employing organization's CSR activities influences not only employee engagement but also a company's performance (Lee, Park, and Lee, 2013). Future research might aim to assess whether different measurements of EO fit operate differently in the model we developed. That is, would findings differ between measures of perceived EO fit (directly reported by the employee), subjective EO fit (calculated indirectly by measuring individual and organizational values via employee reports), and objective EO fit (calculated via employee ratings of their own EO and an independent rating of the organization's EO)?

Finally, future research should examine other dimensions of corporate social responsibility and their fit with corresponding employee values. For example, incorporating environmental and social concerns in investment decisions regarding the company's pension funds might or might not match the employee's priorities. Future studies might also incorporate value congruence effects and mechanisms at different levels of the organizations, such as frontline employees, middle management, corporate executives and directing boards. 


\section{References}

Aiken, L. S. and West, S. G. (1991). Multiple regression: Testing and interpreting interactions. Sage, Thousand Oaks, CA.

Amabile, T. M. (1988). A model of creativity and innovation in organizations. In B. M. Staw and L. L. Cummings LL (Eds.). Research in Organizational Behavior, (pp. 123-167). JAI Press Inc., Greenwich, CT.

Amabile, T. M., Burnside, R., and Gryskiewicz, S. S. (1995). User's guide for KEYS: Assessing the climate for creativity. Center for Creative Leadership, Working Paper, Greensboro, NC.

Amabile, T. M., Conti, R., Coon, H., Lazenby, J., and Herron, M. (1996). Assessing the work environment for creativity. Academy of Management Journal 39(5), 1154-1184.

Ambrose, M. L., Arnaud, A., and Schminke, M. (2008). Individual moral development and ethical climate: The influence of person-organization fit on job attitudes. Journal of Business Ethics 77(3), 323-333.

Aragon-Correa, J.A., Matias-Reche, F., and Senise-Barrio, M. E. (2004). Managerial discretion and corporate commitment to the natural environment. Journal of Business Research 57(9), 964-975.

Arthur, W. Jr., Bell, S. T., Villado, A. J., and Doverspike, D. (2006). The use of personorganization fit in employment decision making: An assessment of its criterion-related validity. Journal of Applied Psychology 91(4), 786-801.

Banerjee, S. B. (2001). Managerial perceptions of corporate environmentalism: Interpretations from industry and strategic implications for organizations. Journal of Management Studies 38(4), 489-513. 
Banerjee, S. B. (2002). Corporate environmentalism: The construct and its measurement. Journal of Business Research 55(3), 177-191.

Baron, R. M., and Kenny, D. A. (1986). The moderator-mediator variable distinction in social psychological research: Conceptual, strategic, and statistical considerations. Journal of Personality and Social Psychology 51(6), 1173-1182.

Bansal, P. (2003). From issues to actions: The importance of individual concerns and organizational values in responding to natural environmental issues. Organization Science 14(5), 510-527.

Becchetti, L., Ciciretti, R., Hasan, I., and Kobeissi, N. (2012). Corporate social responsibility and shareholder's value. Journal of Business Research 65(11), 1628-1635.

Becker-Olsen, K. L., Cudmore, A. B., and Hill, P. R. (2006). The impact of perceived corporate social responsibility on consumer behavior. Journal of Business Research 59(1), 46-53.

Bolton, S. C., Kim, R., and O’Gorman, K. D. (2011). Corporate social responsibility as a dynamic internal organizational process: A case study. Journal of Business Ethics 101(1), 61-74.

Brekke, K. A., and Nyborg, K. (2008). Attracting responsible employees: Green production as labor market screening. Resource and Energy Economics 30(4), 509-526.

Cable, D. M., and Edwards, J. R. (2004). Complementary and supplementary fit: A theoretical and empirical integration. Journal of Applied Psychology 89(5), 822-834.

Chatman, J. A. (1989). Improving interactional organizational research: A model of personorganization fit. Academy of Management Review 14(3), 333-349. 
Chen, Y.-S., and Chang, C.-H. (2013). The determinants of green product development performance: Green dynamic capabilities, green transformational leadership, and green creativity. Journal of Business Ethics 116(1), 107-119.

Choi, J. N. (2004). Person-environment fit and creative behavior: Differential impacts of supplies-values and demands-abilities versions of fit. Human Relations 57(5), 531-552.

Chowdhury, R. M. M. I., and Fernando, M. (2013). The role of spiritual well-being and materialism in determining consumers' ethical beliefs: An empirical study with Australian consumers. Journal of Business Ethics 113(1), 61-79.

Clemens, B. (2006). Economic incentives and small firms: Does it pay to be green? Journal of Business Research 59(4), 492-500.

Dangelico, R. M., and Pujari, D. (2010). Mainstreaming green product innovation: Why and how companies integrate environmental sustainability. Journal of Business Ethics 95(3), 471486.

Dubinsky, A. J., Howell, R. D., Ingram, T. N., and Bellenger, D. (1986). Salesforce socialization. Journal of Marketing 50(4), 192-207.

Edwards, J. R. (2002). Alternatives to difference scores. In F. Drasgow and N. W. Schmitt (Eds.). Advances in measurement and data analysis, (pp. 350-400). Jossey-Bass, San Francisco.

Edwards, J. R., and Cable, D. M. (2009). The value of value congruence. Journal of Applied Psychology 94(3), 654-677.

Edwards, J. R., Caplan, R. D., and Harrison, R. V. (1998). Person-environment fit theory: Conceptual foundations, empirical evidence, and directions for future research. In C. L. 
Cooper (Ed.). Theories of Organizational Stress, (pp. 28-67). Oxford University Press, Oxford, UK.

Edwards, J. R., and Parry, M. E. (1993). On the use of polynomial regression equations as an alternative to difference scores in organizational research. Academy of Management Journal 36(6), 1577-1613.

Edwards, J. R., and Rothbard, N. P. (1999). Work and family stress and well-being: An examination of person-environment fit in the work and family domains. Organizational Behavior and Human Decision Processes 77(2), 85-129.

Fornell, C., and Larcker, D. F. (1981). Evaluating structural equation models with unobservable variables and measurement error. Journal of Marketing Research 18(1), 39-50.

Hansen, S. D., Dunford, B. B., Boss, A. D., Boss, R. W., and Angermeier, I. (2011). Corporate social responsibility and the benefits of employee trust: A cross-disciplinary perspective. Journal of Business Ethics 102(1), 29-45.

Jin, K. G., Drozdenko, R., and DeLoughy, S. (2013). The role of corporate value clusters in ethics, social responsibility, and performance: A study of financial professionals and implications for the financial meltdown. Journal of Business Ethics 112(1), 15-24.

Jordan, J., Brown, M. E., Treviño, L. K., and Finkelstein, S. (2013). Someone to look up to: Executive-follower ethical reasoning and perceptions of ethical leadership. Journal of Management 39(3), 660-683.

Kauffeld, R., Malhotra, A., and Higgins, S. (2009). Green is a strategy. Strategy + Business 57(Winter), http://www.strategy-business.com/article/00013 (accessed on March 1, 2013). 
Koonmee, K., Singhapakdi, A., Virakul, B., and Lee, D. (2010). Ethics institutionalization, quality of work life, and employee job-related outcomes: A survey of human resource managers in Thailand. Journal of Business Research 63(1), 20-26.

Kristof, A. Y. (1996). Person-organization fit: An integrative review of its conceptualizations, measurement, and implications. Personnel Psychology 49(1), 1-49.

Kristof-Brown, A. L., and Billsberry, J. (2013). Fit for the future. In A. L. Kristof-Brown and J. Billsberry (Eds.). Organizational Fit: Key Issues and New Directions (pp. 1-18). John Wiley \& Sons, Ltd., West Sussex, UK.

Kristof-Brown, A. Y., and Guay, R. P. (2011). Person-environment fit. In S. Zedeck (Ed.). APA Handbook of Industrial and Organizational Psychology, vol. 3 (pp. 3-50). American Psychological Association, Washington, DC.

Kristof-Brown, A. Y., Zimmerman, R. D., and Johnson, E. C. (2005). Consequences of individuals' fit at work: A meta-analysis of person-job, person-organization, persongroup, and person-supervisor fit. Personnel Psychology 58(2), 281-342.

Lee, E. M., Park, S.-Y., and Lee, H. J. (2013). Employee perception of CSR activities: Its antecedents and consequences. Journal of Business Research 66(10), 1716-1724.

Menguc, B., and Ozanne, L. K. (2005). Challenges of the "green imperative”: A natural resource-based approach to the environmental orientation-business performance relationship. Journal of Business Research 58(4), 430-438.

Nunnally, J. C. (1978). Psychometric Theory. McGraw-Hill, New York.

O’Reilly, C. A. III, Chatman, J. A., and Caldwell, D. F. (1991). People and organizational culture: A profile comparison approach to assessing person-organization fit. Academy of Management Journal 34(3), 487-516. 
Oldham, G. R., and Cummings, A. (1996). Employee creativity: Personal and contextual factors at work. Academy of Management Journal 39(3), 607-634.

Podsakoff, P. M., MacKenzie, S. B., and Bommer, W. H. (1996). Meta-analysis of the relationships between Kerr and Jermier’s substitute for leadership and employee job attitudes, role perceptions, and performance. Journal of Applied Psychology 81(4), 380399.

Preacher, K. J., and Hayes, A. F. (2008). Asymptotic and resampling strategies for assessing and comparing indirect effects in multiple mediator models. Behavior Research Methods 40(3), 879-891.

Schminke, M., Ambrose, M. L., and Neubaum, D. O. (2005). The effect of leader moral development on ethical climate and employee attitudes. Organizational Behavior and Human Decision Processes 97(2), 135-151.

Shalley, C. E., and Zhou, J. (2008). Organizational creativity research: A historical review. In J. Zhou J. and C. E. Shalley CE (Eds.). Handbook of Organizational Creativity (pp. 3-32). Erlbaum, Hillsdale, NJ.

Shalley, C. E., Zhou, J., and Oldham, G. R. (2004). The effects of personal and contextual characteristics on creativity: Where should we go from here? Journal of Management 30(6), 933-958.

Sharma, S. (2000). Managerial interpretations and organizational context as predictors of corporate choice of environmental strategy. Academy of Management Journal 43(4), 681697.

Shrivastava, P. (1995). Environmental technologies and competitive advantage. Strategic Management Journal 16(S1), 183-200. 
Shrivastava, P. (1996). Greening business: Profiting the corporation and the environment. Thompson Executive, Cincinnati, $\mathrm{OH}$.

Sobel, M. E. (1982). Asymptotic intervals for indirect effects in structural equations models. In S. Leinhart (Ed.). Sociological Methodology (pp. 290-312). Jossey-Bass, San Francisco, CA.

Sorescu, A. B., and Spanjol, J. (2008). Innovation's effect on firm value and risk: Insights from consumer packaged goods. Journal of Marketing 72(2), 114-132.

Strahan, R., and Gerbasi, K. C. (1972). Short, homogenous versions of the Marlow-Crowne social desirability scale. Journal of Clinical Psychology 28(2), 191-193.

Steenkamp, J. E. M., and Gielens, K. (2003). Consumer and market drivers of the probability of new consumer packaged goods. Journal of Consumer Research 30(3), 368-384.

Stone, G. W., and Wakefield, K. L. (2000). Eco-orientation: An extension of market orientation in an environmental context. Journal of Marketing Theory \& Practice 8(3), 21-31.

Surroca, J., Tribo, J. A., and Waddock, S. A. (2010). Corporate responsibility and financial performance: The role of intangible resources. Strategic Management Journal 31(5), 463490.

Tang, T. L.-P. (2010). From increasing gas efficiency to enhancing creativity: It pays to go green. Journal of Business Ethics 94(2), 149-155.

Tierney, P., Farmer, S. M., and Graen, G. B. (1999). An examination of leadership and employee creativity: The relevance of traits and relations. Personnel Psychology 52(3), 591-620.

Waddock, S. A., and Graves, S. B. (1997). The corporate social performance-financial performance link. Strategic Management Journal 18(4), 303-319. 
West, M. A., and Farr, J. L. (1990). Innovation at work. In M. A. West and J. L. Farr (eds.) Innovation and Creativity at Work (pp. 1-13). Wiley, Chichester, England.

Woodman, R. W., Sawyer, J. E., and Griffin, R. W. (1993). Toward a theory of organizational creativity. Academy of Management Review 18(2), 293-321.

Yen, Y., and Yen, S. (2012). Top-management's role in adopting green purchasing standards in high-tech industrial firms. Journal of Business Research 65(7), 951-959.

Zhao, X., Lynch, J. G., and Chen, Q. (2010). Reconsidering Baron and Kenny: Myths and truths about mediation analysis. Journal of Consumer Research 37(2), 197-206.

Zhou, J., and Shalley, C. E. (2003). Research on employee creativity: A critical review and directions for future research. In J. Martocchio (Ed.) Research in Personnel and Human Resource Management (pp. 165-217). Elsevier, Oxford, England.

Zhou, J., and Shalley, C. E. (2011). Deepening our understanding of creativity in the workplace: A review of different approaches to creativity research. In S. Zedeck (Ed.). APA Handbook of Industrial and Organizational Psychology, vol. 1 (pp. 275-302). American Psychological Association, Washington, DC. 
Table 1. Construct Correlations, Means, Standard Deviations (SD), and Square Root of Average Variance Extracted ( $\sqrt{ } A V E$ )

\begin{tabular}{|c|c|c|c|c|c|c|c|c|c|c|c|}
\hline & M & SD & $\sqrt{A V E}$ & $(2)$ & (3) & $(4)$ & $(5)$ & $(6)$ & $(7)$ & $(8)$ & $(9)$ \\
\hline (1) Employee environmental orientation & 4.39 & 1.43 & 0.82 & $.31 * *$ & .19 & .13 & $.24 *$ & .18 & .03 & -.02 & .01 \\
\hline (2) Organizational environmental orientation & 4.24 & 1.43 & 0.85 & -- & $.25^{*}$ & $.38 * *$ & $.38 * *$ & $.46^{* *}$ & .04 & -.06 & -.04 \\
\hline (3) Regulatory pressure & 3.51 & 1.11 & 0.81 & & -- & -.15 & .01 & -.07 & .13 & -.04 & $.21 *$ \\
\hline (5) Creativity & 3.78 & 1.49 & 0.89 & & & & -- & $.79 * *$ & .04 & -.10 & -.12 \\
\hline (6) Organizational encouragement & 4.11 & 1.40 & 0.84 & & & & & -- & .11 & .05 & -.13 \\
\hline (7) Number of years at current organization & 6.01 & 3.00 & -- & & & & & & -- & $.47 * *$ & $.28 * *$ \\
\hline (8) Number of years in current position & 8.67 & 4.50 & -- & & & & & & & -- & $.24 *$ \\
\hline (9) Number of employees at organization & 2,384 & 3,776 & -- & & & & & & & & -- \\
\hline
\end{tabular}

Notes: No correlation is greater than the corresponding $\sqrt{A V E}$, indicating discriminant validity of constructs (Fornell and Larcker, 1981)

-- = single indicator variable; $*=p<0.05 ; * *=p<0.01$ 
Table 2. Polynomial Regression Results of Environmental Orientation (EO) Fit Effects on Employee Job Satisfaction and Creativity

\begin{tabular}{|c|c|c|c|c|c|c|c|c|c|c|}
\hline \multirow{2}{*}{\multicolumn{7}{|c|}{ Fixed Effects Coefficients ${ }^{\mathrm{a}}$}} & \multicolumn{4}{|c|}{ Response Surface Features } \\
\hline & & & & & & & \multicolumn{2}{|c|}{$X=-Y$ misfit line } & \multicolumn{2}{|c|}{$X=Y$ fit line } \\
\hline DV: & $R^{2}$ & I & $\mathrm{O}$ & $\mathrm{I}^{2}$ & $\mathrm{I} \times \mathrm{O}$ & $\mathrm{O}^{2}$ & $\begin{array}{l}\text { Slope } \\
\left(b_{1}-b_{2}\right)\end{array}$ & $\begin{array}{l}\text { Curvature } \\
\left(b_{3}-b_{4}+b_{5}\right)\end{array}$ & $\begin{array}{l}\text { Slope } \\
\left(b_{1}+b_{2}\right)\end{array}$ & $\begin{array}{l}\text { Curvature } \\
\left(b_{3}+b_{4}+b_{5}\right)\end{array}$ \\
\hline Job Satisfaction & $.190 * *$ & .008 & $.299 *$ & -.070 & $.134^{*}$ & .003 & -.291 & -.201 & $.307 * * *$ & $.067 *$ \\
\hline Creativity & $.066 *$ & .097 & $.326 * *$ & -.107 & $.140^{\wedge}$ & .019 & -.228 & -.227 & $.423 * * *$ & $.052 *$ \\
\hline
\end{tabular}

Notes: ${ }^{\text {a}}$ Entries are unstandardized regression coefficients; I = Employee environmental orientation, O = Organizational environmental orientation;

$* * * p<.001, * * p<.01, * p<.05, \wedge p<.10$ 
Table 3. Environmental Orientation (EO) Fit Effects on Job Satisfaction and Creativity

\begin{tabular}{|c|c|c|c|}
\hline Predictor & $B$ & $S E B$ & $\beta$ \\
\hline \multicolumn{4}{|c|}{ (a) Predicting Job Satisfaction $\left(R^{2}=0.62 ; N=90\right)$} \\
\hline Employee environmental orientation & 0.02 & 0.07 & 0.02 \\
\hline Organizational environmental orientation & 0.02 & 0.08 & 0.02 \\
\hline Environmental orientation fit & 0.09 & 0.04 & $0.16^{*}$ \\
\hline Organizational encouragement & 0.66 & 0.08 & $0.76 * *$ \\
\hline Social desirability & -0.19 & 0.15 & -0.09 \\
\hline Years in current position & 0.01 & 0.01 & 0.01 \\
\hline Years at current organization & 0.01 & 0.02 & 0.04 \\
\hline Number of employees at organization & $<0.01$ & $<0.01$ & -0.01 \\
\hline Gender & -0.04 & 0.28 & -0.01 \\
\hline Age & -0.06 & 0.09 & -0.06 \\
\hline Education level & -0.07 & 0.08 & -0.06 \\
\hline \multicolumn{4}{|l|}{ (b) Predicting Creativity $\left(R^{2}=0.71 ; N=90\right)$} \\
\hline Employee environmental orientation & 0.14 & 0.07 & 0.13 \\
\hline Organizational environmental orientation & -0.01 & 0.08 & -0.01 \\
\hline Environmental orientation fit & 0.10 & 0.04 & $0.15^{*}$ \\
\hline Organizational encouragement & 0.81 & 0.08 & $0.77 * *$ \\
\hline Social desirability & -0.21 & 0.15 & -0.09 \\
\hline Years in current position & -0.01 & 0.01 & -0.05 \\
\hline Years at current organization & 0.02 & 0.02 & 0.09 \\
\hline Number of employees at organization & $<0.01$ & $<0.01$ & -0.03 \\
\hline Gender & 0.13 & 0.28 & 0.03 \\
\hline Age & -0.26 & 0.09 & $-0.24 * *$ \\
\hline Education level & 0.06 & 0.08 & 0.05 \\
\hline \multicolumn{4}{|l|}{ (c) Predicting Creativity $\left(R^{2}=0.73 ; N=90\right)$} \\
\hline Employee environmental orientation & 0.13 & 0.07 & 0.13 \\
\hline Organizational environmental orientation & -0.01 & 0.07 & -0.01 \\
\hline Environmental orientation fit & 0.08 & 0.04 & 0.12 \\
\hline Job satisfaction & 0.23 & 0.01 & $0.20^{*}$ \\
\hline Organizational encouragement & 0.67 & 0.11 & $0.63^{* *}$ \\
\hline Social desirability & -0.16 & 0.15 & -0.07 \\
\hline Years in current position & -0.01 & 0.01 & -0.06 \\
\hline Years at current organization & 0.02 & 0.02 & 0.08 \\
\hline Number of employees at organization & $<0.01$ & $<0.01$ & -0.03 \\
\hline Gender $\quad P=0$ & 0.14 & 0.28 & 0.04 \\
\hline Age & -0.25 & 0.09 & $-0.22 * *$ \\
\hline Education level & 0.07 & 0.08 & -0.06 \\
\hline
\end{tabular}

Notes: Regression models are estimated with all predictors entered simultaneously. $B=$ unstandardized coefficient; $S E B=$ standard error of $B ; \beta=$ standardized coefficient; $*=p<0.05 ; * *=p<0.01$ 
Table 4a. Regulatory Pressure as Moderator of the Environmental Orientation (EO) FitJob Satisfaction Relationship

\begin{tabular}{lccc}
\hline \multicolumn{1}{c}{ Predictor } & $B$ & $S E B$ & $\beta$ \\
\hline Predicting Job Satisfaction $\left(R^{2}=0.67 ; N=90\right)$ & & & \\
Employee environmental orientation & 0.11 & 0.07 & 0.12 \\
Organizational environmental orientation & 0.10 & 0.08 & 0.11 \\
Environmental orientation (EO) fit & 0.09 & 0.04 & $0.16^{*}$ \\
Regulatory pressure (RP) & -0.16 & 0.09 & -0.14 \\
EO fit x RP & -0.14 & 0.05 & $-0.23^{* *}$ \\
Organizational encouragement & 0.60 & 0.08 & $0.65 * *$ \\
Social desirability & -0.14 & 0.14 & -0.07 \\
Years in current position & $<0.01$ & 0.01 & -0.01 \\
Years at current organization & 0.02 & 0.02 & 0.09 \\
Number of employees at organization & $<0.01$ & $<0.01$ & -0.07 \\
Gender & -0.16 & 0.27 & -0.05 \\
Age & -0.12 & 0.09 & -0.13 \\
Education level & -0.03 & 0.08 & -0.03 \\
\hline
\end{tabular}

Notes: Regression model is estimated with all predictors entered simultaneously.

$B=$ unstandardized coefficient; $S E B=$ standard error of $B ; \beta=$ standardized

coefficient; $*=p<0.05 ; * *=p<0.01$

Table 4b. Moderated Environmental Orientation (EO) Fit Effects on Creativity with Job Satisfaction as Mediator

\begin{tabular}{lrcc}
\hline \multicolumn{1}{c}{ Predictor } & $B$ & SE B & $\beta$ \\
\hline Predicting Creativity $\left(R^{2}=0.74 ; N=90\right)$ & & & \\
Employee environmental orientation & 0.09 & 0.08 & 0.08 \\
Organizational environmental orientation & -0.05 & 0.08 & -0.04 \\
Environmental Orientation (EO) Fit & 0.07 & 0.04 & 0.11 \\
Regulatory Pressure (RP) & 0.04 & 0.09 & 0.03 \\
EO Fit x RP & 0.07 & 0.05 & 0.11 \\
Job satisfaction & 0.28 & 0.12 & $0.24^{*}$ \\
Organizational encouragement & 0.66 & 0.11 & $0.62^{* *}$ \\
Social desirability & -0.17 & 0.15 & -0.07 \\
Years in current position & -0.01 & 0.01 & -0.05 \\
Years at current organization & 0.01 & 0.02 & 0.06 \\
Number of employees at organization & $<0.01$ & $<0.01$ & -0.01 \\
Gender & 0.20 & 0.28 & 0.05 \\
Age & -0.22 & 0.09 & -0.20 \\
Education level & 0.06 & 0.08 & 0.05 \\
\hline
\end{tabular}

Notes: Regression model is estimated with all predictors entered simultaneously.

$B$ = unstandardized coefficient; $S E B=$ standard error of $B ; \beta=$ standardized coefficient; $*=p<0.05 ; * *=p<0.01$ 
Figure 1. Conceptual Model

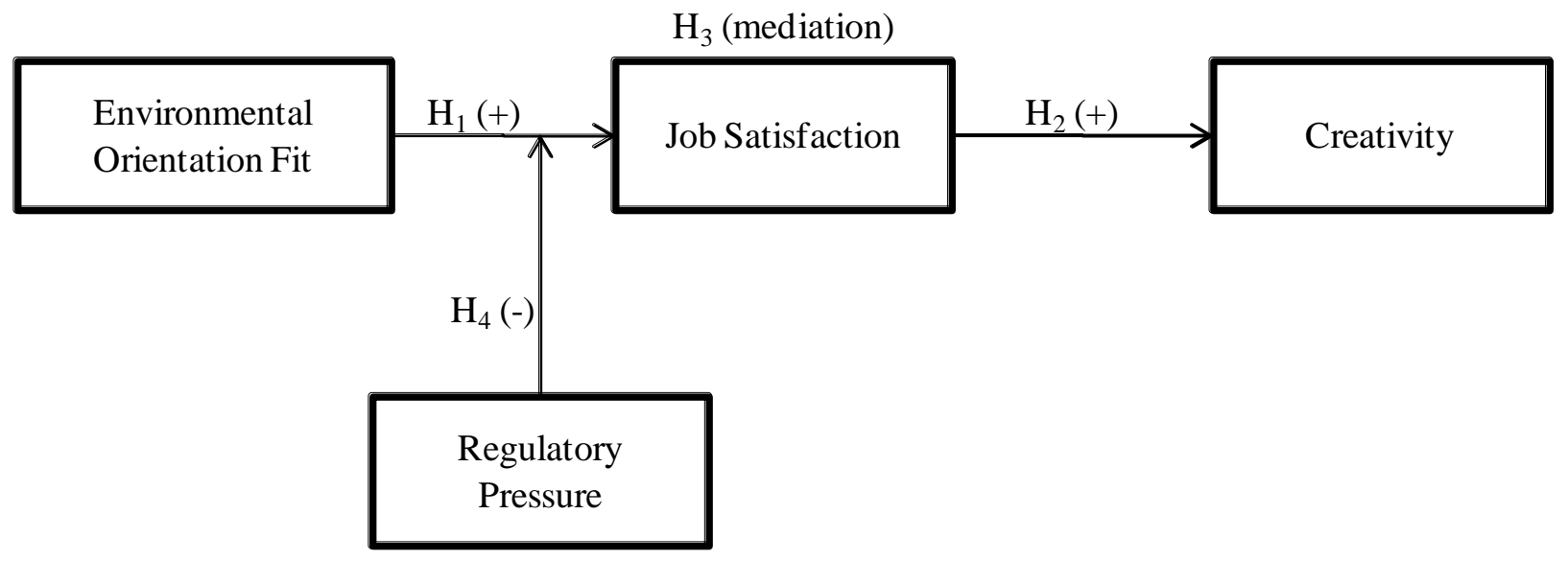


Figure 2. Response Surface Methodology: Environmental Orientation (EO) Fit Effect (Employee Orientation as X and Organizational Orientation as $\mathrm{Y}$ ) on Job Satisfaction (Z)

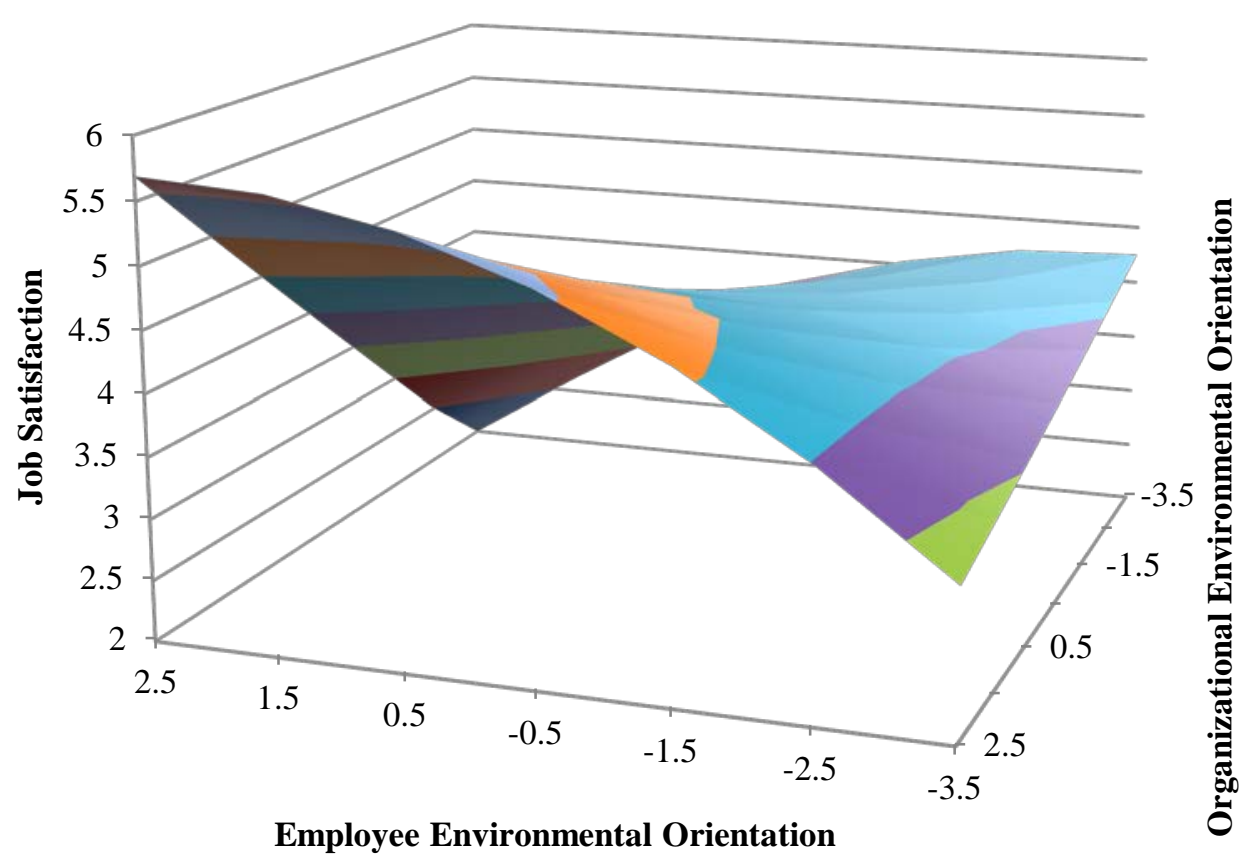


Figure 3. Response Surface Methodology: Environmental Orientation (EO) Fit Effect (Employee Orientation as X and Organizational Orientation as Y) on Creativity (Z)

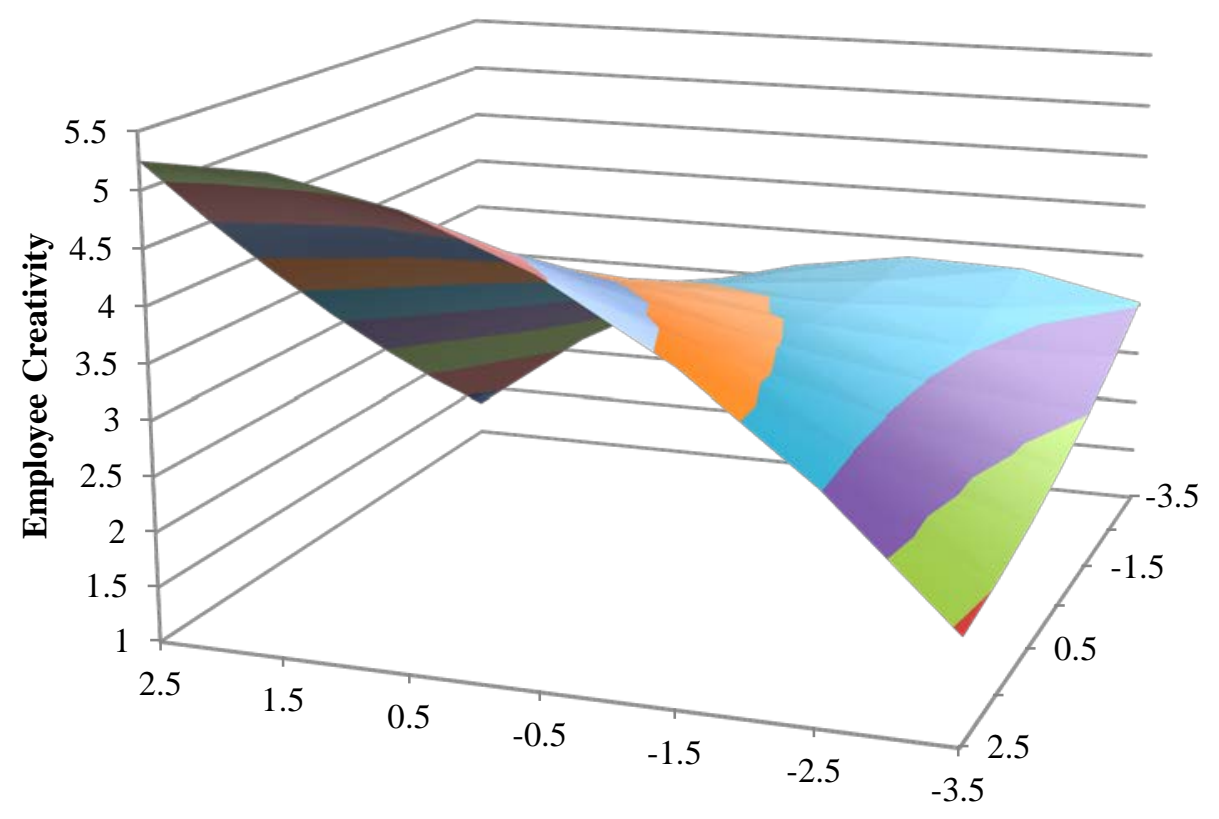

Employee Environmental Orientation

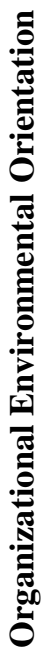


Figure 4. Simple Regression Slopes for Environmental Orientation (EO) Fit Effect on Job Satisfaction Moderated by Regulatory Pressure

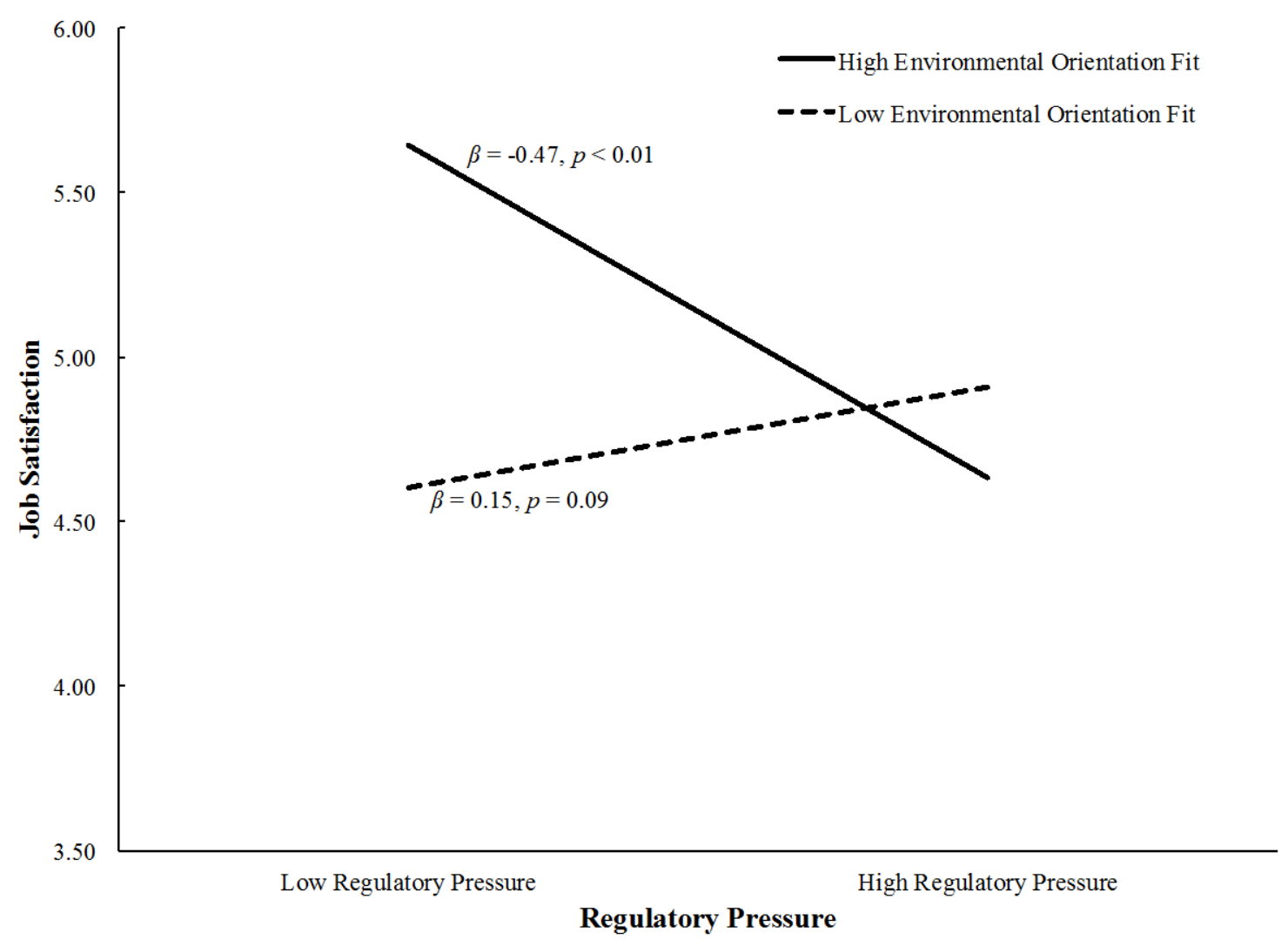

Notes: Simple regression slopes are reported as unstandardized betas. 
Figure 5. Decomposed Moderated Environmental Orientation (EO) Fit Effect on Job Satisfaction

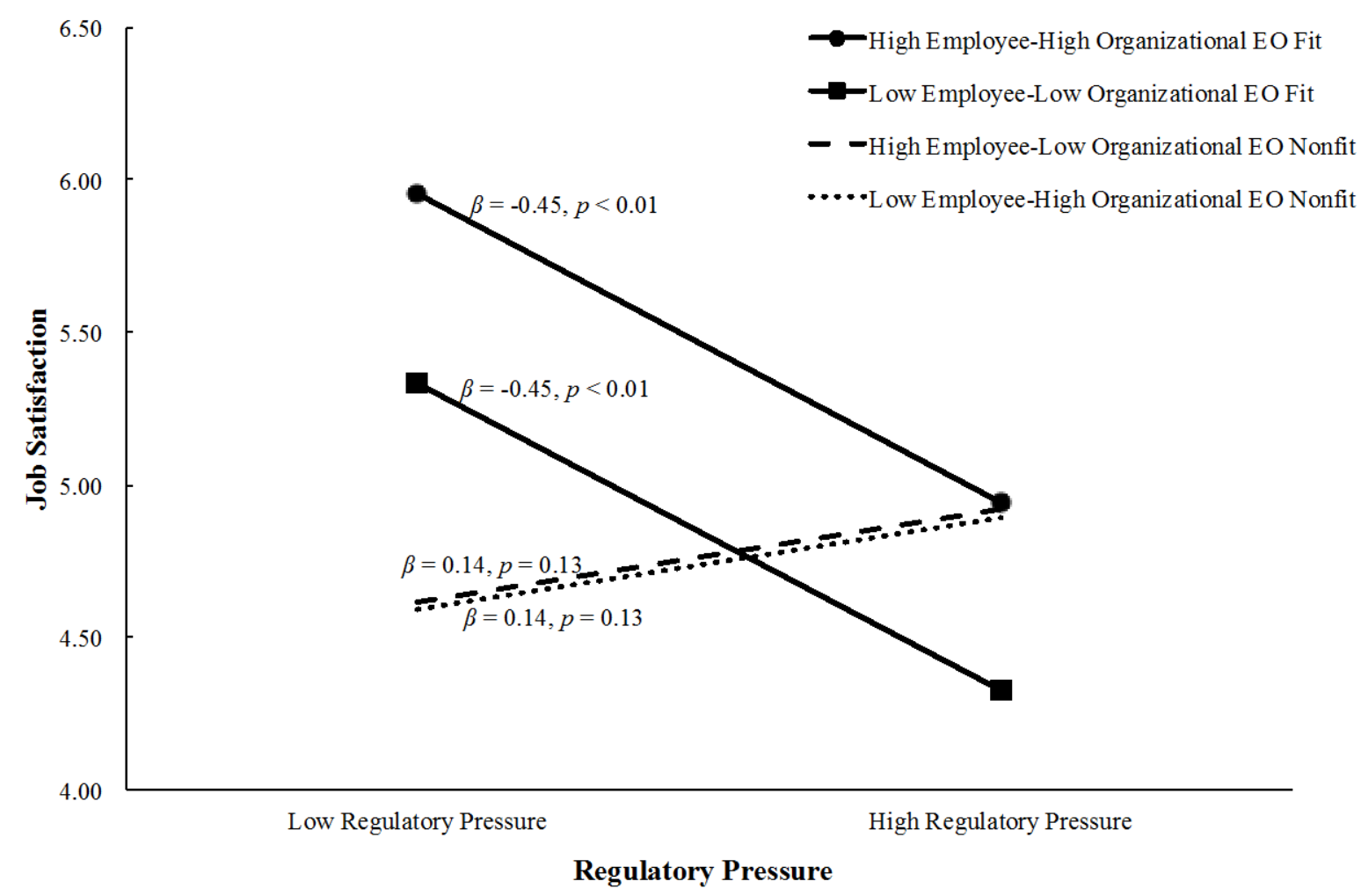

Notes: Simple regression slopes are reported as unstandardized betas. $\mathrm{EO}=$ environmental orientation. 